\title{
Technology Adaption As Survival Strategy For Small And Medium Enterprises During COVID-19
}

Ashraf Mishrif ( $\square$ ashraf.mishrif@gmail.com )

Sultan Qaboos University https://orcid.org/0000-0003-4237-4206

Asharul Khan

Sultan Qaboos University

\section{Research}

Keywords: Small and Medium Enterprises, Covid-19, technology adaption, operation, impact.

Posted Date: November 19th, 2021

DOI: https://doi.org/10.21203/rs.3.rs-1074106/v1

License: (c) (i) This work is licensed under a Creative Commons Attribution 4.0 International License. Read Full License 


\section{Abstract}

Globally, business and operational capabilities of Small and Medium Enterprises (SMEs) have been enormously affected by the Covid-19 pandemic, forcing many to use technology and innovation rather than the more traditional methods of operations. Although we do not yet know to the extent to which Oman's SMEs have adopted these technological transformations, we investigate this, and assess the impact of it, in this study. We empirically examine how Covid-19 accelerated technology use in the SMEs in Oman and test nine hypotheses applying paired t-test and Pearson correlation. The results show strong correlations between technology use before and during Covid-19 $(r=.823, p<0.01)$; technology use during Covid-19 and in future $(r=.659, p<0.01)$; and technology use before Covid-19 and in future $(r=.612, p<0.01)$. We conclude that this use of technology has been a survival strategy during the pandemic and that highly digitized SMEs are more likely to adopt Industry 4.0 technology.

\section{Introduction}

Small Medium Enterprises have been negatively affected globally in the Covid-19 pandemic. Huge financial losses and even closures of some companies have resulted from enforced lockdowns and limited demand and purchasing power. In the United States the number of active small businesses reduced by $22 \%$ from February to April 2020 (Fairlie, 2020). To a large extent, a country's economic growth depends on its SMEs (Belsito and Reutzel, 2019; Didonet and Diaz-Villavicencio, 2020; Na-Nan and Wongsuwan, 2020; Rafiki, 2020). Zafar and Mustafa (2017) support this view, with evidence showing SMEs in high-income countries contribute to over $55 \%$ of GDP and over $65 \%$ of total employment, whilst in low-income nations; they contribute over $60 \%$ of GDP and over $70 \%$ of total employment. Ninety five percent (95\%) of the total employment and approximately $70 \%$ of GDP come from SMEs in middle-income countries.

SMEs face an uncertain future, despite fundamental efforts from governments and large companies to keep them afloat, according to a recent study conducted in the USA, which evaluated Covid-19's impact on them (Bartik et al., 2020c). Some SMEs have survived through the pandemic by stimulus programs and contributions; however, it is difficult to ensure they will endure if the negative impacts continue. Bartik et al. (2020a) also feared that Small Medium Enterprises may suffer long-term Covid-19 impacts. Lu et al. (2020) support this conclusion by pointing out that, although China was first to recover from the pandemic, SMEs still face a challenging future there considering the risk that other waves may continue for years.

Innovation will be required to bring about desperately needed changes for SMEs. Although many analyses recommend financial support from the governments, including Juergensen et al. (2020) and Pedauga et al. (2021), it will be technology that leads SMEs to superior performance and competitive advantage. Abed (2021) systematically reviewed the literature on Covid-19's impact and technology role in reducing the effect on businesses and perceived that technology was an essential element in SMEs' survival. Unfortunately, however, there are only 11 studies which examined this role of technology in developed countries and there is a larger research gap on the digital transformation of SMEs in developing countries (Amornkitvikai and Lee, 2020; Hassen et al., 2019). In the Covid-19 era, SMEs' survival depends on the ability to adapt to new market mechanisms in a way that helps them to gain a competitive advantage in the global market (Baporikar and Shikokola, 2020). Consumers were able to continue many of their tasks with the help of Amazon, Google Cloud, Facebook, Microsoft Azure, Zoom, Netflix, and Slack. Small companies, however, did not seem to grasp the benefits of, and have not acquired the digital skills for, running their businesses online (Antonescu, 2020). There is a higher probability of SMEs adopting technology once they realize the benefits and impact on performance (Scupola, 2009; Shah Alam et al., 2011).

In Oman, regrettably, many businesses are either temporarily or permanently closed due to the indirect or direct impacts of Covid-19 (Afifi and Negm, 2020). The Omani government made critical decisions to overcome negative effects of the pandemic. Ali and Mukhaini (2020) believed Oman would contain the pandemic based on its success in containing other outbreaks, such as SARS and H1N1 between 2002 -2012. Magd and McCoy (2014) studied the contributions of SMEs to the national economy in Oman and concluded that SMEs need to improve in the arena of technological innovation if they are to flourish. According to Abed (2021), there has only been one research paper from the Arab world (MENA and GCC) and this was in Saudi Arabia, where Salem and Nor (2020) investigated SMEs and technology adoption during Covid-19. Surprisingly, there has been little empirical research globally on this aspect of the pandemic (Billore and Billore, 2020; Doyle and Conboy, 2020; Salem and Nor, 2020), hence there is a need to conduct study using primary data for the role of technology and adoption in SMEs' survival during Covid19.

In light of this, it is critical to understand any current technological transformations by Oman's SMEs and the issues they have faced, and are facing, whilst undergoing these changes. We will seek to answer the following research questions 1) How has Covid-19 accelerated technological transformation and new technologies the SMEs introduced during Covid-19? 2) How has the technological transformation helped SMEs to manage their operations during the Covid-19 crisis? Furthermore, we will investigate the levels of satisfaction and future technological innovation plans in SMEs.

Loading [MathJax]/jax/output/CommonHTML/jax.js 
Although the qualitative research method is useful for in-depth and detailed analysis, it does not help much in generalization. Consequently, in addition to interviews, an online questionnaire was distributed covering various industries to test the hypotheses. Because this is the first investigation on this topic conducted in Oman and GCC, the results of this study would help the Omani SMEs to better understand the digital transformation concept and its role on business performance. In addition, the Omani government will benefit from the findings, which can be used to develop strategy and policies for helping the national SMEs. We expect this research to also be beneficial in assisting other developing countries in exploring better strategies and developing future plans.

There are seven sections: Section 2 communicates the literature review; Section 3 describes the research method; Section 4 presents analysis and findings; Section 5 offers our discussion; Section 6 summarizes the findings; and the last section suggests recommendations.

\section{Literature Review}

\subsection{Impact of Covid-19 lockdowns on SMEs}

All manner of businesses has been negatively affected by Covid-19 lockdowns: restaurants, supermarkets, fitness centers, traditional food markets, cinemas, car dealerships, or any operation which requires physical space as opposed to online markets. Countries' investment, trade, and economy have all been affected by the pandemic (Gössling et al., 2020), culminating in a decreased cash flow due to lesser consumer demand (Priyono et al., 2020).

Verma and Gustafsson (2020) analyzed 107 published papers in Scopus, then summarized the business situation during Covid-19 lockdown into four categories: overall impact on business, technology, supply chain management, and service industry. Over 5,800 small businesses were surveyed by Bartik et al. (2020b). The results highlighted huge numbers of layoffs, closures, financial loss, and funding expectations. A qualitative study using interviews, conducted by Nyanga and Zirima (2020), found that SMEs encountered disrupted operations and employees' layoff due to Covid-19. Seetharaman (2020) agreed that decreased revenue in small businesses led to employees losing their jobs. Lu et al. (2020) assessed 4,807 SMEs in China by conducting online surveys and interviews. Their study indicates SMEs' operational problems were due to unavailability of materials, supply chain disruptions, unavailability of workforce, reduced market demand, and cash flow. Belghitar et al. (2021) examined the performance of a further 42,401 SMEs across 28 industries during Covid-19 with research indicating that $59 \%$ of the UK's SMEs will have negative earnings unless the government funds them. SMEs in Serbia were investigated by Beraha and Duricin (2020). The empirical analysis of online surveys showed the impact on SMEs' daily operations having varying intensity due to lockdowns. Scottish SMEs showed loss of revenue and the need for financial assistance for enterprises with higher risk of bankruptcy and closure (Brown, 2020). Antonescu (2020) highlighted impacts on the Romanian SME sector. Pakistan's SMEs are forecast for slow growth, higher costs of production, and a more intense impact due to the pandemic lockdowns (Javed and Ayaz, 2020).

A survey of 748 Malaysian SMEs by Ratnasingam (2020) on the Covid-19 assessment reported financial management and supply chain disruptions as the major challenges. Robinson and Kengatharan (2020) interviewed 14 SMEs in Sri Lanka, with the result indicating material shortages, a decline in the global and local demand for products and services, difficulties when repaying loans and interest, order cancellations, and a lack of savings. The 456 households and 144 small firms from both urban and rural areas in Nord Kivu underwent telephone surveys by Desbureaux et al. (2020). The analysis found a decline in economy. In short, thousands of SMEs are in the process of closure. We suggest, for a start, communication between entrepreneurs and local or central authorities, increasing the guarantee ceiling, and higher flexibility between funds, private, and public investments.

\subsection{Technology as a survival strategy adopted by SMEs}

While reviewing the literature that examined the strategies and role of technology in SME survival, we identified the following studies. A study into how business strategies are affected by differences in gender, age, education, and income level was undertaken by Untaru and Han (2021), concluding with the suggestion that retailers should develop dissimilar communication strategies for different customer segments, in accordance with these targeted demographic profiles. The intention would be to increase protective measures against Covid-19, endure the pandemic and avoid too many losses. Thorgren and Williams (2020) conducted a study on 456 struggling SMEs to explore the survival strategies adopted during Covid-19. The result demonstrates that SMEs deferred investments, reduced labor costs and other expenses, and negotiated contracts and terms. Survival strategies adopted by Malaysian SMEs because of Movement Control Order (MCO) were examined by Omar et al. (2020). The qualitative analysis of six telephonic interviews indicates changes in financial and marketing approaches.

Fitriasari (2020) presented a business model for SMEs to handle pandemics. This model consists of product excellence, public behavior, and process reliability. It highlights factors necessary for digital transformation as digital skills, infrastructure testing, and tools adoption. Hussain, Shahzad et al. (2021) assessed the impact of technological (relative advantage and technology readiness), organizational (cost of adoption and top management support), and environmental (government support and competitive pressure) factors on B2B e-commerce for manufnaturina CM MFo in Dalintan Thn multi-group analysis of the collected data predicted significant impact of technological factors on B2B e- 
commerce. In the Indonesian SMEs' business model, Priyono et al. (2020) investigated changes and digital transformations with the help of a multiple case study involving seven manufacturing enterprises. Observations, interviews, and field visits were used as techniques. The result demonstrated dissimilar degrees of digital transformation in SMEs with a high level of digital maturity, those experiencing liquidity issues with a low level of digital maturity, and the SMEs that have a very limited level of digital literacy.

Big data analytics is the technology designed to economically extract value from massive volumes of a wide variety of data by enabling highvelocity capture, discovery, and analysis (Khan and Al-Badi, 2020a). This technology facilitates innovative and customer-centric post-sale services and offers feedback for better product design and marketing (Akpan et al., 2020). Big data and predictive and visual analytics enable complex business decisions, while Artificial Intelligence (Al) involves learning, reasoning, and self-correction. Computer Vision is an essential enabling technology that sensibly enhances the outcomes, acting as a unifying element in many applications and a facilitator and integrator of other techniques (Khan and Al-Habsi, 2020). As recently as this year, Luo (2021) conducted a study using Deep Recurrent Neural Network (DRNN) on clickstream information for exploring the effect of social networks and online shopping behavior on E-Business performance during the pandemic. Results showed that this deep learning technique is effective in modelling consumer behavior, and the model was able to improve the profitability ratio by $98.5 \%$, the performance ratio by $97.5 \%$, the accuracy ratio by $96.7 \%$, the prediction ratio by $97.9 \%$, and give less error rate than the other approaches by $11.3 \%$.

Although Papadopoulos et al. (2020) presented an opinion paper and discussed the research on the role of digital technologies in improving productivity and performance in SMEs during Covid-19, they argued limited research on the use and adoption of these technologies to deal with the challenges of the crisis. Their paper further highlights issues of infrastructure, finance, skilled workforce, and security constraints. After proposing a digital transformation and sustainability framework for SMEs to handle pandemics. Winarsih et al. (2021) reported lack of knowledge amongst the enterprises on the benefits of digital skills. The leaders from 15 Indian hi-tech start-ups from various industries were interviewed on understanding the role of technology in business survival, in a case study by Jha (2020). The result indicates acceptance of new technologies and major transformation in the business model. Marin Bustamante (2020) reviewed the literature on the role of new technologies (big data and analytics, artificial intelligence, mobile payments, internet of things, and block chain) in business during the lockdowns. The review revealed that 65 papers published from 2011 to 2020 show no study on the influence of new technologies in firms' internationalization in the context of the Covid-19 pandemic. Dwivedi et al. (2020) examined twelve subject experts' views on Covid-19 and information management research and practice. These specialists presented different perspectives regarding digital strategy, artificial intelligence, information management, social interactions, cyber security, big data, block chain, privacy, mobile technology, and strategy. loT refers to the connections of machines, computers, and people enabling intelligent industrial operations for transformational business outcomes, with benefits closed-loop design, increased consumer value, predictive maintenance, new service lines, and reduced labor cost (Khan and Al-Badi, 2020b; McKnight, 2017). The paradigm of cloud computing enables the leasing of computing resources in real-time, with minimal interaction with the provider for cost-saving, seamless implementation, and simplification (Attaran and Woods, 2019; Thames and Schaefer, 2016).

During the Covid-19 crisis, FinTech companies helped workers, entrepreneurs, and entire economies. Smeets and Zeisberger (2020) argued the benefits and use of FinTech in Latin America during this period. Simultaneously, in Saudi Arabia, Salem and Nor (2020) investigated consumer intention to adopt e-commerce. The research empirically identified factors of perceived lack of alternatives, perceived behavioral control, and government support, which significantly influence the embracing of online spending. In Bangladesh, 665 consumers were surveyed on the attitude of digital marketing of branded cosmetics, and Akter and Sultana (2020) discovered a positive attitude towards digital platforms during the lockdown. Commerce and business involve a transaction of goods and services between buyers and sellers, as defined by Alharbi and de Doncker (2019) and Taleby Ahvanooey et al. (2020), while E-business is described as an Internet based transaction (Galindo-Martín et al., 2019). Social media and E-commerce shops have seen growth during the pandemic and consumers regularly searched for essential products online. Companies are using social media and online techniques to distribute product information for sales and to predict revenue trend (Lv et al., 2020). The effectiveness of a social network-based E-business strategy is measured by how well consumers use retreats, likes, and shares to engage with the company's advertisements. Social networking is used in advertising and promotional activities (Sathishkumar et al., 2020) and online marketing (Kumari et al., 2020).

Through necessity, the shopping habits of various regions have changed (Bartik et al., 2020a; Bartik et al., 2020b) and digital transformation requires moving from offline stores to online, for consumer health, safety, and convenience. Fletcher and Griffiths (2020) suggested technology as the best solution for business sustainability during the pandemic. It is important for companies not to look at Covid-19 as an obstacle, since adoption of online digital channels can increase their promotion and sales (Doyle and Conboy, 2020). Each business, whether large or small, is crucial for the economy and therefore their sustainability, by adopting technologies, is essential in the current and future environment (Ameen et al., 2021).

\section{Research Method}

Loading [MathJax]/jax/output/CommonHTML/jax.js 
In this study, broad literature on technology and SMEs has been referenced. We used mixed methods, consisting of both qualitative and quantitative approaches, for in-depth analysis and to add a broader set of aspects and skills that help researchers to collect, analyze, compare, and conclude findings. Mixed methods research provides strengths to both quantitative and qualitative methods, enhancing the research to be more explored and diverse (Shorten and Smith, 2017). It also develops relationships between the research questions and connects the results to reach coherent conclusions, in addition to enriching understanding of the business field (Molina-Azorin, 2016). The mixed method employed gives a very comprehensive and varied analysis through using interviews and questionnaires. International sources from databases and journals were also very useful in compiling the results of this paper.

\subsection{Research hypotheses}

The survey questionnaire and interviews were designed to meet the research objective and designed in a manner to conduct the analysis and hypotheses testing. The study seeks to tests the following null hypotheses.

$\mathrm{H1}$ : There is no correlation between technology use by SMEs before and during Covid-19

$\mathrm{H} 2$ : There is no correlation between technology use by SMEs before Covid-19 and in future

H3: There is no correlation between technology uses by SMEs during Covid-19 in future

H4: There is no correlation between customer satisfaction and technology use by SMEs during Covid-19

H5: There is no correlation between customer satisfaction and SMEs' performance during Covid-19

H6: There is no correlation between SMEs' company size and digitalization during Covid-19

H7: There is no correlation between Industry 4.0 technology use by SMEs during Covid-19 and in future

H8: There is no difference in the technology use by SMEs before and during Covid-19

In addition, we will seek to find answers to the following intuitions: What level of digitalization do SMEs currently have? Which Industry 4.0 technologies do SMEs plan to use in the future?; What is the rate of company satisfaction with the quality of its E-Service?; and What is the rate of customer satisfaction with the quality of the company's E-Service.

\subsection{Statistical models for hypotheses testing}

The paired t-test and Pearson correlation were used here. The hypotheses were tested at $p<0.01$ or $p<0.05$. The correlation $r$ values are: .00.19 "very weak"; .20- .39 "weak"; .40- .59 "moderate"; .60- .79 "strong"; .80- 1.0 "very strong" (Evans, 1996). The thematic and content approach was employed to generate the results of textual data and initial general themes were pre-determined before starting the coding process. These general themes (innovation, operation, and strategy) guided the analysis, but an open coding was also deployed for new emerging themes.

Pearson correlation coefficient (bivariate correlation): It is a measure of linear correlation between two sets of data. It not only indicates the presence or absence of a correlation between two variables, but it also assists in determining the strength of the association between the two variables (Rice, 2006). It also determines the direction of correlation, or whether two variables have a negative or positive correlation. The Pearson correlation presupposes that data is sampled at random and that the variables have a continuous and normal distribution. The formula to calculate Pearson correlation is as follows:

$$
r_{x y}=\frac{n\left(\sum x y\right)-\left(\sum x\right)\left(\sum y\right)}{\sqrt{\left[n \sum x^{2}-\left(\sum x\right)^{2}\right] \cdot\left[n \sum y^{2}-\left(\sum y\right)^{2}\right]}}
$$

1

Where, $r=$ Pearson coefficient, $n=$ number of the pairs of the stock, $\sum x y=$ sum of products of the paired stocks, $\sum x=$ sum of the $x$ scores, $\sum y=$ sum of the $y$ scores, $\sum x^{2}=$ sum of the squared $x$ scores, $\sum y^{2}=$ sum of the squared $y$ scores

The ' $r$ ' can take on any value between ' -1 ' and ' +1 '. The value ' 0 ' denotes that there is no link between the two variables. $A$ value greater than ' 0 ' indicates a positive relationship between two variables, suggesting that an increase in the value of one variable raises the value of the other. $A$ value less than ' 0 ' indicates a negative relationship between two variables, indicating that raising the value of one decreases the value of the other.

Loading [MathJax]/jax/output/CommonHTML/jax.js 
It is an inferential statistical analysis approach invented by William Sealy Gosset in 1908. A t-test is conducted to see if there is a difference between the means of two groups that are related in some way (Kendall, 1946). The assumptions for t-test distribution include random sampling, independent sampling of data from the same population, and normal distribution (e.g., tested applying Kolmogorov-Smirnov test). Additionally, when the standard deviations of samples are almost equal, homogeneous, or equal, variance exists.

Paired t-test (t-test with correlation) examines the difference between two paired samples i.e. the difference in the sample means used for a paired t-test should be 0 . It is used when the samples are made up of matched pairs of similar units, or when there are repeated measures. It's possible, for example, that the same object/entity will be examined multiple times-both before and after a treatment. This method can also be used in situations when the samples are related or have similar traits. The formula to calculate paired t-test for two sample groups (1 and 2 ) is as follows:

$$
t=\frac{\overline{X_{1}}-\bar{X}_{2}}{\sqrt{\frac{S_{1}^{2}+S_{2}^{2}-2 \rho S_{1} S_{2}}{n}}}
$$

Where, $\mathrm{n}=$ sample size, $\bar{X}_{1}, \bar{X}_{2}=$ means of samples, $\mathrm{s}_{1}{ }^{2}, \mathrm{~s}_{2}{ }^{2}=$ variance

\subsection{Data collection}

We gathered data from SMEs all over Oman. Both online and offline modes were used in survey questionnaire distribution and conducting interviews from February 10, 2021, to April 20, 2021. The CEO, directors, managers, and executives from both private and public sectors were interviewed, with the consent of each respondent taken before interviewing and completing surveys. We explained to them the purpose of the study and they were assured of complete confidentiality of their personal data. The collected data were cleaned for missing and incomplete values. The total number of relevant samples used for the analysis was 214 . In addition to this data a qualitative analysis of 10 interviews was also performed. The SPSS 26.0 and NVivo 12.0 software packages were used in quantitative and qualitative data analysis, to establish the relationships between variables and constraints. Following data analysis, the results were brainstormed, then visualized as graphs and charts. The research team discussed and evaluated the results before final documentation. The main characteristics and percentages of valid responses of the survey participants are explained in Table 1. 
Table 1

Characteristics of Survey Participants and Companies

\begin{tabular}{|llll|}
\hline Gender & Percent & Business Operation & Percent \\
\hline Male & 67.76 & Oil and gas & 0.93 \\
\hline Female & 32.24 & Electricity service & 0.93 \\
\hline Total & 100.00 & Marine and fishing & 0.93 \\
\hline Position & Percent & Food service & 10.75 \\
\hline Director & 41.59 & Manufacturing & 5.61 \\
\hline CEO & 16.82 & Finance & 0.93 \\
\hline General Manager & 14.49 & Healthcare & 1.40 \\
\hline HR Manager & 1.40 & Education & 3.27 \\
\hline Finance Manager & 1.40 & Travel and Tourism & 3.74 \\
\hline Operation Manager & 0.93 & social clubs & 12.15 \\
\hline Employee & 6.54 & Media and entertainment & 2.80 \\
\hline Other & 16.82 & Construction & 14.02 \\
\hline Total & 100.00 & logistics and supply chain & 1.87 \\
\hline Number of Offices & Percent & ICT & 1.40 \\
\hline One & 60.28 & Wholesale (Food and others) & 2.34 \\
\hline Two to five & 33.18 & Consultancy & 2.80 \\
\hline Six to ten & 3.74 & Home business & 7.94 \\
\hline More than ten & 2.80 & Sanad office & 0.93 \\
\hline Total & 100.00 & Other & 25.23 \\
\hline & & Total & 100.00 \\
\hline
\end{tabular}

\section{Results}

We used a wide variety of companies and respondents for our data collection, sampling from public and private companies, Omani and nonOmani owners, male and female, local and international traders, and from CEOs to employees. The Cronbach alpha is 7.1, which is under the acceptable range. The surveyed companies comprise public (84.58\%), private (11.21\%), public-private (2.80\%), and non-profit (1.40\%), with offices in Muscat (37.85\%), Al-Batinah South (7.48\%), Al-Batinah North (39.25\%), Al-Dakhaliyah (7.48\%), Al-Buraimi (1.40\%), Musandam (3.27\%), Dhofar (1.40\%), Al-Dhahirah (1.40\%), Al-Wusta (0.47\%). Most of these companies are more than 10 years (40.19\%), some 3 to 5 years (27.57\%), 6 to 10 years (19.63\%), and less than 2 years (12.62\%). They serve the public (49.53\%), business-to-consumer (37.85\%), and business-to-business (12.62\%). Most of them trade locally and few of them export goods. The Omani owners account for $90.19 \%$ and nonOmanis $9.81 \%$. There are $67.76 \%$ male respondents and $32.24 \%$ female, their positions in the companies vary form Director, CEO, General Manager, HR Manager, Finance Manager, Operation Manager, to employee. Majority of the SMEs has low level of digitization such as payment via VISA card etc. For instance, high (e.g. using cloud system, online payment, and no printing (8.4\%), moderate (e.g. cloud system, online payment, and less printing (22.9\%), low (e.g. traditional way of communicating and cash/VISA payment only (68.7\%). Figure 1 shows the level of digitization in SMEs in Oman.

The paired t-test for technology use before and during the pandemic shows strong positive correlation $(r=.823, p<0.01)$ and there is a significant average difference between technology use before and during the pandemic $\left(t_{213}=-2.153, p<0.05\right)$. On average score technology use during Covid-19 was 13.1 points higher than technology use before the pandemic (95\% $\mathrm{Cl}[1.1,25.1])$. This indicates that the mean technology use score during Covid-19 $(M=2.54)$ was significantly higher than the mean before Covid-19 $(M=2.41)$. The technology use was independent of the number of branches and company's age. Table 2 shows Pearson's correlation matrix of selected variables. 
Table 2

Pearson's correlation between selected variables

\begin{tabular}{|c|c|c|c|c|c|c|c|c|c|}
\hline & & $\begin{array}{l}\text { Customer } \\
\text { type }\end{array}$ & $\begin{array}{l}\text { Type of } \\
\text { business }\end{array}$ & $\begin{array}{l}\text { Impact on } \\
\text { performance }\end{array}$ & $\begin{array}{l}\text { Impact } \\
\text { on } \\
\text { sales }\end{array}$ & $\begin{array}{l}\text { Customer } \\
\text { satisfaction }\end{array}$ & $\begin{array}{l}\text { Technology } \\
\text { use before } \\
\text { pandemic }\end{array}$ & $\begin{array}{l}\text { Technology } \\
\text { use during } \\
\text { pandemic }\end{array}$ & $\begin{array}{l}\text { Technology } \\
\text { use in } \\
\text { future }\end{array}$ \\
\hline \multirow[t]{2}{*}{$\begin{array}{l}\text { Customer } \\
\text { type }\end{array}$} & $\begin{array}{l}\text { Pearson } \\
\text { Correlation }\end{array}$ & 1 & & & & & & & \\
\hline & $\begin{array}{l}\text { Sig. (2- } \\
\text { tailed) }\end{array}$ & & & & & & & & \\
\hline \multirow[t]{2}{*}{$\begin{array}{l}\text { Type of } \\
\text { business }\end{array}$} & $\begin{array}{l}\text { Pearson } \\
\text { Correlation }\end{array}$ & $.156^{\star}$ & 1 & & & & & & \\
\hline & $\begin{array}{l}\text { Sig. (2- } \\
\text { tailed) }\end{array}$ & 0.023 & & & & & & & \\
\hline \multirow[t]{2}{*}{$\begin{array}{l}\text { Impact on } \\
\text { performance }\end{array}$} & $\begin{array}{l}\text { Pearson } \\
\text { Correlation }\end{array}$ & $.273^{\star \star}$ & $.173^{\star}$ & 1 & & & & & \\
\hline & $\begin{array}{l}\text { Sig. (2- } \\
\text { tailed) }\end{array}$ & 0 & 0.011 & & & & & & \\
\hline \multirow[t]{2}{*}{$\begin{array}{l}\text { Impact on } \\
\text { sales }\end{array}$} & $\begin{array}{l}\text { Pearson } \\
\text { Correlation }\end{array}$ & 0.127 & -0.02 & $.322^{\star \star}$ & 1 & & & & \\
\hline & $\begin{array}{l}\text { Sig. (2- } \\
\text { tailed) }\end{array}$ & 0.063 & 0.776 & 0 & & & & & \\
\hline \multirow[t]{2}{*}{$\begin{array}{l}\text { Customer } \\
\text { satisfaction }\end{array}$} & $\begin{array}{l}\text { Pearson } \\
\text { Correlation }\end{array}$ & $.146^{\star}$ & $.143^{\star}$ & $.237 \star \star$ & -0.015 & 1 & & & \\
\hline & $\begin{array}{l}\text { Sig. (2- } \\
\text { tailed) }\end{array}$ & 0.032 & 0.037 & 0 & 0.828 & & & & \\
\hline \multirow{2}{*}{$\begin{array}{l}\text { Technology } \\
\text { use before } \\
\text { pandemic }\end{array}$} & $\begin{array}{l}\text { Pearson } \\
\text { Correlation }\end{array}$ & $.218^{\star \star}$ & $.139 *$ & 0.118 & 0.096 & $.156^{\star}$ & 1 & & \\
\hline & $\begin{array}{l}\text { Sig. (2- } \\
\text { tailed) }\end{array}$ & 0.001 & 0.042 & 0.084 & 0.164 & 0.023 & & & \\
\hline \multirow{2}{*}{$\begin{array}{l}\text { Technology } \\
\text { use during } \\
\text { pandemic }\end{array}$} & $\begin{array}{l}\text { Pearson } \\
\text { Correlation }\end{array}$ & $.203^{\star \star}$ & $.215^{\star \star}$ & $.138 *$ & $.174^{\star}$ & $.209 \star \star$ & $.823^{\star \star}$ & 1 & \\
\hline & $\begin{array}{l}\text { Sig. (2- } \\
\text { tailed) }\end{array}$ & 0.003 & 0.002 & 0.044 & 0.011 & 0.002 & 0 & & \\
\hline \multirow[t]{2}{*}{$\begin{array}{l}\text { Technology } \\
\text { use in future }\end{array}$} & $\begin{array}{l}\text { Pearson } \\
\text { Correlation }\end{array}$ & $.168^{\star}$ & $.159 *$ & 0.07 & $.217^{\star \star}$ & $.159 *$ & $.612^{\star \star}$ & $.659 \star \star$ & 1 \\
\hline & $\begin{array}{l}\text { Sig. (2- } \\
\text { tailed) }\end{array}$ & 0.014 & 0.02 & 0.305 & 0.001 & 0.02 & 0 & 0 & \\
\hline
\end{tabular}

There is strong correlation between technology use before and during Covid-19 $(r=.823, p<0.01)$, technology use during Covid-19 and in future $(r=.659, p<0.01)$, and technology use before the pandemic and in future $(r=.612, p<0.01)$. There is also correlation between customers satisfaction and sales $(r=.175, p<0.05)$ and technology use before Covid-19, during Covid-19, and in future $(r=.156, p<0.05 ; r=.209, p<$ $0.01 ; r=.159, p<0.05)$. On further investigation, we learned that different SME owners and entrepreneurs found some innovative ways to overcome pandemic impacts and to reduce effects on their profits. Around half of the interviewees said that using technology such as Emarketing helped to reach out to the customers during the lockdown:

"Whatever I have done until today is almost enough to come out of any situations. To have more of online communications with customers. Wherever I put my products, people online already know about it. This communication is very important to come out of any situation. Plus, I am planning to export outside as well. Also, we tied up with Mazoon Souq and online websites that charge for registration and commission as per the sale of the products. They pay you after 45 days." [RC034]

Another interviewee explained how the pandemic helped them learn new technology and explore other tools even from outside Oman:

"We use a Russian software, and it is perfect for everything. We design innovative tools ourselves and the workers make them using machines." 
The customer and company have high level of satisfactions with the eService. For instance, satisfaction of company from eService- strongly dissatisfied (6.1\%), dissatisfied (9.8\%), neutral (40.7\%), satisfied (28.0\%), and strongly satisfied (15.4\%), Satisfaction of customer from eService- strongly dissatisfied (6.1\%), dissatisfied (3.7\%), neutral (43.0\%), satisfied (28.5\%), and strongly satisfied (18.7\%). Figure 2 shows the satisfaction of customers and companies with eService during Covid-19.

In line with some recent studies that argue the pandemic has hastened technology transfer in various economic sectors, including SMEs, the data we gathered shows innovation development in business and SME sectors in Oman: this is indeed positive progress. Supporting this, some scholars argue that innovative technologies such as FinTech, which is a crowdfunding platform, not only provide competitive advantages but also offer "a means for survival, by improvising existing business models" (Akpan et al., 2020: 7). Two of the interviewees mentioned a high cost of using technology and innovation in the present time; this could be attributable to the limited market access to innovation and technology solutions. Unfortunately, not many companies provide innovative products and services, as it is a new field in business and SME sectors. There are, however, many opportunities for new start-ups in innovation solutions that the private sector, entrepreneurs and even the government should consider.

Many businesses survived this pandemic by learning and adopting new technical strategies. For example, the business-to-business marketing strategy uses retailers sharing information about stock levels and involves technological collaboration between businesses of similar industrial sectors. Crick and Crick (2020) recognize this helped to limit the negative impacts of the Covid-19 pandemic. A similar strategy of forming business alliances can be adopted in Oman to help the SMEs sector survive this crisis. We questioned the respondents about the current state of Industry 4.0 technology and future use and discovered there exists a strong correlation between the industry 4.0 technology current use and future use $(r=.322, p<0.01)$. One business owner's perception of Industry 4.0 technology follows:

"We are planning to invest in Artificial Intelligence, big data, machine learning, and biometrics soon. We will hire a consultant to help us improving in these areas. Our systems are ready for data analysis, so when we are ready to use it, we will be able to analyze the market and avoid technical problems." [T-RC024]

While the company size and level of digitalization are related, albeit weakly $(r=.189, p<0.01)$, this is not related to Industry 4.0 technology current and future use. Table 3 shows this correlation.

Table 3

Correlation between Industry 4.0 technology current and future use

\begin{tabular}{|c|c|c|c|c|}
\hline & & $\begin{array}{l}\text { Level of } \\
\text { digitalization }\end{array}$ & $\begin{array}{l}\text { Industry } 4.0 \text { technology } \\
\text { current use }\end{array}$ & $\begin{array}{l}\text { Industry } 4.0 \text { technology use in } \\
\text { future }\end{array}$ \\
\hline \multirow[t]{2}{*}{$\begin{array}{l}\text { Industry } 4.0 \text { technology } \\
\text { current use }\end{array}$} & $\begin{array}{l}\text { Pearson } \\
\text { Correlation }\end{array}$ & $.322^{\star \star}$ & & \\
\hline & Sig. (2-tailed) & 0.000 & & \\
\hline \multirow[t]{2}{*}{$\begin{array}{l}\text { Industry } 4.0 \text { technology use in } \\
\text { future }\end{array}$} & $\begin{array}{l}\text { Pearson } \\
\text { Correlation }\end{array}$ & $.226^{\star \star}$ & $.572^{\star \star}$ & \\
\hline & Sig. (2-tailed) & 0.001 & 0.000 & \\
\hline \multirow[t]{2}{*}{ Company size } & $\begin{array}{l}\text { Pearson } \\
\text { Correlation }\end{array}$ & $.189^{\star \star}$ & 0.106 & 0.113 \\
\hline & Sig. (2-tailed) & 0.006 & 0.123 & 0.099 \\
\hline
\end{tabular}

The survey questionnaire analysis on the use of Industry 4.0 technology in future found that more preference of cloud computing (48\%), followed by Artificial Intelligence (23\%), and big data (23\%). Figure 3 shows the participants willingness to use Industry 4.0 technology in terms of types and percentage.

Overcoming challenges during the pandemic have improved the strategies used in businesses and SMEs. Moreover, strategizing skills of entrepreneurs and business owners have also advanced. Four out of ten interviewees confirmed that they had to change their strategy and explore new ones and therefore started learning new approaches to survive this pandemic. This entrepreneur said of their explorations:

"We know Oman is a small market, and our technology is borderless. Since day one, we have been planning to sell our product aboard. We have already started to study the licenses and operation process in other countries, and we have already talked to some companies from GCC and maybe will reach agreement with some of them soon." [T-RC004]

Loading [MathJax]/jax/output/CommonHTML/jax.js 
Our data show more issues related to operation than other themes. We found that the companies' operation $(r=.146, p<0.01)$ and performance $(r=.237, p<0.01)$ were influenced by customers' satisfaction. Revenue was affected due to operation $(r=.456, p<0.01)$, performance $(r=.299, p<0.01)$, and type of business/company $(r=.134, p<0.05)$.

Additionally, risk of insolvency was associated with operation $(r=.468, p<0.01)$, performance $(r=.303, p<0.01)$, and revenues $(r=.313, p<$ 0.01). Figure 4 shows the relationship between selected variables.

The null hypotheses $(\mathrm{H} 1$ to $\mathrm{H} 8)$ proposed in the study are rejected. Table 4 shows the results of the hypotheses upon testing.

Table 4

Results of hypotheses testing

\begin{tabular}{|c|c|c|}
\hline Hypotheses & Correlation values & Accept/Reject \\
\hline $\mathrm{H} 1$ : There is no correlation between technology use by SMEs before and during Covid-19 & $r=.823, p<0.01$ & Reject \\
\hline $\mathrm{H} 2$ : There is no correlation between technology use by SMEs before Covid-19 and in future & $r=.612, p<0.01$ & Reject \\
\hline H3: There is no correlation between technology use by SMEs during Covid-19 and in future & $r=.659, p<0.01$ & Reject \\
\hline $\begin{array}{l}\text { H4: There is no correlation between customer satisfaction and technology use by SMEs during } \\
\text { Covid-19 }\end{array}$ & $r=.209, p<0.01$ & Reject \\
\hline H5: There is no correlation between customer satisfaction and SMEs performance during Covid-19 & $r=.237, p<0.01$ & Reject \\
\hline H6: There is no correlation between SMEs' company size and digitalization during Covid-19 & $r=.189, p<0.01$ & Reject \\
\hline $\begin{array}{l}\text { H7: There is no correlation between Industry } 4.0 \text { technology use by SMEs during Covid-19 and in } \\
\text { future }\end{array}$ & $r=.322, p<0.01$ & Reject \\
\hline H8: There is no difference in the technology use by SMEs before and during Covid-19 & $\begin{array}{l}t_{213}=-2.153, p< \\
0.05\end{array}$ & Reject \\
\hline
\end{tabular}

\section{Discussion}

It is clear from the study that the SMEs acted swiftly, embracing measures such as technology adoption and product and marketing innovations. The Omani Government has been able to curtail the effects of the Covid-19 pandemic and responded well in the healthcare area, however it also needs to act quickly to prevent economic and societal devastation to SMEs in Oman. The study offers several insightful and potentially useful policy interventions, alongside practical implications for SMEs. The research recommends actions based on how the SMEs addressed and responded to the challenges presented during an unforeseen external shock.

The pandemic has been an opportunity for SMEs to re-invent themselves by adopting modern technologies. Furthermore, SMEs have less competition from foreign companies, thus they can enhance production to meet local demands in the areas of manufacturing, food and beverage, and agriculture. As a direct result of Covid-19, manufacturing firms in developed countries have moved from a conventional to an ecommerce business model (Shahzad et al., 2020), with Oman following suit and applying technological innovation. In general, the way SMEs have been using digital solutions for e-commerce has completely changed. In Oman, SMEs adopted new strategies and business models, which ensured their survival and enabled them to market their products during the Covid-19 era. Many industries have changed their business model to online, helping them to remain competitive (Hussain et al., 2021). The four common perspectives which have been considered by SMEs in industrialized countries to establish efficiency and sustain their businesses are: infrastructure development, technological investments, technology implementation, and technology adoption.

\subsection{Infrastructure and management support}

Oliveira and Martins (2010) declared the IT infrastructure and technical skills of employees to be crucial factors in an organization's success for technology innovation in the value chain. The implementation of technology in SMEs requires top management support (Singh et al., 2019). In addition, advanced IT infrastructure in these enterprises contributes more towards competition and position. Fletcher and Griffiths (2020) studied the digital transformation among businesses during Covid-19and concluded there is a need to attain digital maturity; less digitally mature organizations have greater fragility, and a higher level of digital maturity among organizations allows greater flexibility.

\subsection{Technological investment}

The regulatory support from the government and financial support from commercial institutions could help SMEs in accepting and using the latest technologies for their operations. Usually, organizations complain of the high cost of technology adoption, although the relative pdvantana nuarchadniwe tho nonvantianal hysiness processes (Shahzad et al., 2020). Promotion of financing schemes, training, reskilling and Loading [MathJax]/jax/output/CommonHTML/jax.js 
development programs are needed in parallel with simplified financing and support centers at governorate and regional level for legal and financial advice, human resources, digitization, and business model innovation. The surveyed organizations complained that technology adoption in SMEs is low due to higher cost and shortage of adequate funds. In developing countries, adoption cost of technology usage is a substantial factor for SMEs (Elahi and Hassanzadeh, 2009; Mohtaramzadeh et al., 2018). To improve the overall technology implementation and adoption climate significantly, the SMEs will need to address trainings, workshops, and aggressively follow the persuasion policies.

\subsection{Technology implementation}

Digital transformation needs to be conducted continuously for sustaining customer satisfaction and an edge over competitors. With digitization, as the volume of data grows, the business needs to develop resources for data governance and management. The digital transformation for SMEs must be supported by governments and stakeholders, yet finance with supplementary funds for digitization, technological transfer, and innovation cannot be elucidated since the number of affected SMEs remains unknown. Development of online platforms for these enterprises to sell their products is required to provide support for domestic producers and local businesses.

\subsection{Technology adoption}

The lockdown has forced many retail outlets worldwide to provide online shopping and it is expected that this trend will continue post pandemic. E-commerce has created a competitive advantage, increased productivity, and improved scheduling for the number of staff, campaigns, acquisitions, and other costs. In an empirical study by Hussain et al. (2020) competitive pressure led to e-commerce adoption. Increased competitive pressure leads to more use of the information system in SMEs (Ocloo et al., 2018). Baporikar (2015) said SMEs are the lifeblood of any economy. In light of this, Oman should create a suitable system for entrepreneurship, which is considered globally to be the raw fuel for creating jobs. Furthermore, considering Omani people have only two ways of securing a job, by entering the public or private sectors, entrepreneurship could be the third option for self-employment and youth employment. In this way, SMEs in Oman would gradually begin to lead in creating jobs for the people.

\section{Conclusion}

This study underscores the importance of technology in business and economic development, especially where countries face economic situations emanating from crises such as COVID-19 or move fast towards the fourth industrial revolution. Cutting-edge technologies add competitive advantages by improving existing business models and business strategies drive the innovation and reengineering processes. The power of Al, machine learning, loT, robots, and data analytics can be leveraged by businesses for sustainability, resilience, and improved business continuity. The Covid-19 pandemic caused SMEs to take up new strategies that effectively and efficiently added value to their businesses. This is illustrated through quantitative and qualitative analyses of technological transformation in SMEs.

The study offers substantial contributions to literature on the roles of innovative or advanced technologies to enhance the operations activities, create competitive advantages, and enhance growth. These have become the survival means for many businesses, which were compelled to adopt technologies due to unusual disruptions in commerce. The lockdowns have accelerated, projected, and magnified the impact of technology. We found strong correlations between technology uses pre- Covid-19, during Covid-19, and in future. The use of technology leads to higher satisfaction among customers, SME performances, and sales. We also found that highly digitized SMEs are more likely to adopt Industry 4.0 technology in future.

The study acknowledges its limitations of the coverage of only Omani SMEs and the short duration of eighteen months since the outbreak of Covid-19. It also realizes the emergence of several new Covid-19 strains that makes it difficult to have a firm conclusion on the technology acceleration rate and their impacts on SMEs. Thus, we recommend the conduct of similar studies in the ensuing weaves of Covid-19 for comparison.

\section{Abbreviations}

Al : Artificial Intelligence

IOT : Internet of Things

SMEs : Small and Medium Enterprises

\section{Declarations}

\section{-Availability of data and materials:}

Loading [MathJax]/jax/output/CommonHTML/jax.js 
Not applicable

\section{-Competing interests}

The authors declare that they have no known competing financial interests or personal relationships that could have appeared to influence the work reported in this paper.

\section{-Funding}

The paper received financial support from the Ministry of Higher Education, Scientific Research and Innovation, Oman. Grant No: RC/COVIDDVC/HURC/20/01

\section{-Authors' contributions}

Ashraf Mishrif: conceptualization, methodology, software, data collection, writing-original draft, reviewing and editing, supervision, funding acquisition. Asharul Khan: conceptualization, methodology, software, data collection, visualization, Writing-original draft paper, resources.

\section{-Acknowledgements}

The authors would like to thank the Ministry of Higher Education, Research and Innovation for the generous funding to support our research project on the impact of Covid-19 on Omani economy. Grant No RC/COVID-DVC/HURC/20/01.

\section{-Authors' information (optional)}

Ashraf Mishrif is Oman Chamber of Commerce and Industry Chair in Economic Studies, Humanities Research Center, Sultan Qaboos University, Oman. He was previously senior lecturer at King's College London, UK.

Asharul Khan, Research Assistant, Humanities Research Center, Sultan Qaboos University, Oman.

\section{References}

1. Abed, S. S. (2021). A literature review exploring the role of technology in business survival during the Covid-19 lockdowns. International Journal of Organizational Analysis

2. Afifi, G. M. H., \& Negm, M. M. F. (2020). Geological sites as a safe resort for post-Covid-19 tourism: The case of Al Jabal Al Akhdar, Oman. Journal of Environmental Management and Tourism, 11(6), 1520-1536

3. Akpan, I. J., Soopramanien, D., \& Kwak, D. H. (2020). Cutting-edge technologies for small business and innovation in the era of Covid-19 global health pandemic. Journal of Small Business \& Entrepreneurship,1-11

4. Akter, M., \& Sultana, N. (2020). Digital marketing communication and consumer buying decision process in pandemic standpoint (Covid19): an empirical study of Bangladeshi customers' in branded cosmetics perspective. Open Journal of Business and Management, 8(06), 2696

5. Alharbi, A. S. M., \& de Doncker, E. (2019). Twitter sentiment analysis with a deep neural network: An enhanced approach using user behavioral information. Cognitive Systems Research, 54, 50-61

6. Ali, A., \& Mukhaini, M. (2020). Covid-19 in the Gulf Special Coverage Covid-19 and Plummeting Oil Prices; a Time of Reckoning for Oman. (April)

7. Ameen, N., Tarhini, A., Reppel, A., \& Anand, A. (2021). Customer experiences in the age of artificial intelligence. Computers in Human Behavior, 114(2021), 1-14

8. Amornkitvikai, Y., \& Lee, C. (2020). Determinants of E-Commerce Adoption and Utilisation by SMEs in Thailand

9. Antonescu, D. (2020). Supporting small and medium size enterprises through the Covid-19 crisis in Romania. Central European Journal of Geography and Sustainable Development, 2(1), 38-57

10. Attaran, M., \& Woods, J. (2019). Cloud computing technology: improving small business performance using the Internet. Journal of Small Business and Entrepreneurship, 31(6), 495-519

11. Baporikar, N. (2015). Entrepreneurship in Sultanate of Oman. International Journal of Asian Business and Information Management, 6(4), 14-26

12. Baporikar, N., \& Shikokola, S. (2020). Information Technology Adoption Dynamics for SMEs in the Manufacturing Sector of Namibia. International Journal of ICT Research in Africa and the Middle East (IJICTRAME), 9(2), 60-77

Loading [MathJax]/jax/output/CommonHTML/jax.js 
13. Bartik, A. W., Bertrand, M., Cullen, Z., Glaeser, E. L., Luca, M., \& Stanton, C. (2020a). The impact of Covid-19 on small business outcomes and expectations. Proceedings of the National Academy of Sciences, 117(30), 17656-17666

14. Bartik, A. W., Bertrand, M., Cullen, Z. B., Glaeser, E. L., Luca, M., \& Stanton, C. T. (2020b). How are small businesses adjusting to Covid-19? Early evidence from a survey. Cambridge, Massachusetts: National Bureau of Economic Research

15. Bartik, A. W., Bertrand, M., Cullen, Z. B., Glaeser, E. L., Luca, M., \& Stanton, C. T. (2020c). How are small businesses adjusting to Covid-19? early evidence from a survey (No. 0898-2937): National Bureau of Economic Research

16. Belghitar, Y., Moro, A., \& Radić, N. (2021). When the rainy day is the worst hurricane ever: the effects of governmental policies on SMEs during Covid-19.Small Business Economics,1-19

17. Belsito, C. A., \& Reutzel, C. R. (2019). SME employee performance appraisal formalization and trust in leadership change.International Journal of Organizational Analysis

18. Beraha, I., \& Đuričin, S. (2020). The impact of Covid-19 crisis on medium-sized enterprises in Serbia. Economic Analysis, 53(1), 14-27

19. Billore, S., \& Billore, G. (2020). Consumption switch at haste: insights from Indian low-income customers for adopting Fintech services due to the pandemic. Transnational Marketing Journal, 8(2), 197-218

20. Brown, R. (2020). The impact of Covid-19 on Scottish small and medium-sized enterprises (SMEs): prognosis and policy prescription. Fraser of Allander Economic Commentary, 44(2)

21. Crick, J. M., \& Crick, D. (2020). Coopetition and Covid-19: Collaborative business-to-business marketing strategies in a pandemic crisis. Industrial Marketing Management, 88, 206-213

22. Desbureaux, S., Kaota, A., Lunanga, E., Stoop, N., \& Verpoorten, M. (2020). Covid-19 vs. Ebola: Impact on households and SMEs in Nord Kivu, DR Congo, 1-25

23. Didonet, S., \& Diaz-Villavicencio, G. (2020). Innovation management in market-oriented SMEs: learning and internal arrangements for innovation. International Journal of Organizational Analysis

24. Doyle, R., \& Conboy, K. (2020). The role of IS in the Covid-19 pandemic: A liquid-modern perspective. International Journal of Information Management, 55, 102184

25. Dwivedi, Y. K., Hughes, D. L., Coombs, C., Constantiou, I., Duan, Y., Edwards, J. S., et al. (2020). Impact of Covid-19 pandemic on information management research and practice: Transforming education, work and life. International Journal of Information Management, 55,102211

26. Evans, R. (1996). An analysis of Criterion Variables Reliability in Conjoint analysis. Perceptual and Motor Skills, 82(3), 988-990

27. Elahi, S., \& Hassanzadeh, A. (2009). A framework for evaluating electronic commerce adoption in Iranian companies. International Journal of Information Management, 29(1), 27-36

28. Fairlie, R. W. (2020). The impact of Covid-19 on small business owners: Evidence of early-stage losses from the April 2020 current population survey. National Bureau of Economic Research

29. Fitriasari, F. (2020). How do Small and Medium Enterprise (SME) survive the Covid-19 outbreak? Jurnal Inovasi Ekonomi, 5(2), 53-62

30. Fletcher, G., \& Griffiths, M. (2020). Digital transformation during a lockdown. International Journal of Information Management, 55(2020), $1-3$

31. Galindo-Martín, M., Castaño-Martínez, M. S., \& Méndez-Picazo, M. T. (2019). Digital transformation, digital dividends and entrepreneurship: A quantitative analysis. Journal of business research, 101, 522-527

32. Gössling, S., Scott, D., \& Hall, C. M. (2020). Pandemics, tourism and global change: a rapid assessment of Covid-19. Journal of Sustainable Tourism, $1-20$

33. Hassen, H., Abd Rahim, N. H., \& Shah, A. (2019). Analysis of models for e-commerce adoption factors in developing countries. International Journal on Perceptive and Cognitive Computing, 5(2), 72-80

34. Hussain, A., Shahzad, A., \& Hassan, R. (2020). Organizational and Environmental Factors with the Mediating Role of E-Commerce and SME Performance. Journal of Open Innovation: Technology, Market, and Complexity, 6(4), 196

35. Hussain, A., Shahzad, A., Hassan, R., \& Doski, S. A. (2021). Covid-19 impact on B2B e-commerce: A multi-group analysis of sports and surgical SME's. Pakistan Journal of Commerce and Social Sciences (PJCSS), 15(1), 166-195

36. Javed, S. A., \& Ayaz, M. U. (2020). Projected impact of lockdown on SMEs in Pakistan

37. Jha, C. (2020). The Great Disruptive Transformation: The Impact of Covid-19 Crisis on Innovative Startups in India. University of Gottenberg

38. Juergensen, J., Guimón, J., \& Narula, R. (2020). European SMEs amidst the Covid-19 crisis: assessing impact and policy responses. Journal of Industrial and Business Economics, 47(3), 499-510

39. Kendall, M. G. (1946). 'The advanced theory of statistics', The advanced theory of statistics., No. 2nd Ed

40. Khan, A. I., \& Al-Badi, A. (2020a). emerging data sources in decision making and Al. Procedia Computer Science, 177, 318-323

Loading [MathJax]/jax/output/CommonHTML/jax.js

Page $13 / 17$ 
41. Khan, A. I., \& Al-Badi, A. (2020b). Open source machine learning frameworks for industrial internet of things. Procedia Computer Science, $170,571-577$

42. Khan, A. I., \& Al-Habsi, S. (2020). Machine learning in computer vision. Procedia Computer Science, 167, 1444-1451

43. Kumari, A., Behera, R. K., Sahoo, K. S., Nayyar, A., Kumar Luhach, A., \& Sahoo, P. (2020). S. Supervised link prediction using structured-based feature extraction in social network. Concurrency Computation

44. Lu, Y., Wu, J., Peng, J., \& Lu, L. (2020). The perceived impact of the Covid-19 epidemic: evidence from a sample of 4807 SMEs in Sichuan Province, China. Environmental Hazards, 19(4), 323-340

45. Luo, C. (2021). Analyzing the impact of social networks and social behavior on electronic business during Covid-19 pandemic. Information Processing \& Management, 58(5), 102667

46. Lv, J., Wang, T., Wang, H., Yu, J., \& Wang, Y. (2020). A SECPG model for purchase behavior analysis in social e-commerce environment. International Journal of Communication Systems, 33(6), 1-13

47. Magd, H. A. E., \& McCoy, M. P. (2014). Entrepreneurship in Oman: Paving the Way for a Sustainable Future. Procedia Economics and Finance, 15(14), 1632-1640

48. Marin Bustamante, D. F. (2020). The role of new technologies in international business in the context of Covid-19: a literature review. Milano: Politecnico

49. McKnight, M. (2017). loT, industry 4.0, industrial loT why connected devices are the future of design. KnE Eng, 2(2), 197-202

50. Mohtaramzadeh, M., Ramayah, T., \& Jun-Hwa, C. (2018). B2B e-commerce adoption in Iranian manufacturing companies: Analyzing the moderating role of organizational culture. International Journal of Human-Computer Interaction, 34(7), 621-639

51. Molina-Azorin, J. F. (2016). Mixed methods research: An opportunity to improve our studies and our research skills. European Journal of Management and Business Economics, 25(2), 37-38

52. Na-Nan, K., \& Wongsuwan, N. (2020). Development and validation of perceived workplace support for small and medium-sized enterprise employees. International Journal of Organizational Analysis

53. Nyanga, T., \& Zirima, H. (2020). Reactions of small to medium enterprises in masvingo, zimbabwe to Covid 19: Implications on productivity. Business Excellence and Management, 10(1), 22-32

54. Ocloo, C. E., Xuhua, H., Akaba, S., Addai, M., Worwui-Brown, D. K., \& Spio-Kwofie, A. (2018). B2B E-commerce Adoption amongst manufacturing SMEs: An Evidence from Ghana.Australian Journal of Economics and Management Sciences, 8(1)

55. Oliveira, T., \& Martins, M. F. (2010). Information technology adoption models at firm level: review of literature. Paper presented at the The European Conference on Information Systems Management

56. Omar, A. R. C., Ishak, S., \& Jusoh, M. A. (2020). The impact of Covid-19 Movement Control Order on SMEs' businesses and survival strategies. Malaysian Journal of Society and Space, 16(2), 139-150

57. Papadopoulos, T., Baltas, K. N., \& Balta, M. E. (2020). The use of digital technologies by small and medium enterprises during Covid-19: Implications for theory and practice. International Journal of Information Management, 55(2020), 1-4

58. Pedauga, L., Sáez, F., \& Delgado-Márquez, B. L. (2021). Macroeconomic lockdown and SMEs: the impact of the Covid-19 pandemic in Spain. Small Business Economics

59. Priyono, A., Moin, A., \& Putri, V. N. A. O. (2020). Identifying digital transformation paths in the business model of smes during the Covid-19 pandemic. Journal of Open Innovation: Technology, Market, and Complexity, 6(4), 1-22

60. Rafiki, A. (2020). Determinants of SME growth: an empirical study in Saudi Arabia.International Journal of Organizational Analysis

61. Ratnasingam, J., Khoo, A., Jegathesan, N., Wei, L. C., Latib, H. A., Thanasegaran, G., et al. (2020). How are small and medium enterprises in Malaysia's furniture industry coping with Covid-19 pandemic? Early evidences from a survey and recommendations for policymakers. BioResources, 15(3), 5951-5964

62. Rice, J. A. (2006). 'Mathematical statistics and data analysis'. Cengage Learning

63. Robinson, J., \& Kengatharan, N. (2020). Exploring the effect of Covid-19 on small and medium enterprises: Early evidence from Sri Lanka. Journal of Applied Economics \& Business Research, 10(2), 115-124

64. Salem, M. A., \& Nor, K. M. (2020). The effect of Covid-19 on consumer behaviour in Saudi Arabia: Switching from brick and mortar stores to E-Commerce. International Journal of Scientific \& Technology Research, 9(07), 15-28

65. Sathishkumar, V. E., Agrawal, P., Park, J., \& Cho, Y. (2020). Bike sharing demand prediction using multiheaded convolution neural networks. BASIC \& CLINICAL PHARMACOLOGY \& TOXICOLOGY, 126, 264-265

66. Scupola, A. (2009). SMEs'e-commerce adoption: perspectives from Denmark and Australia. Journal of Enterprise Information Management 67. Seetharaman, P. (2020). Business models shifts: Impact of Covid-19. International Journal of Information Management, 54, 102173

Loading [MathJax]/jax/output/CommonHTML/jax.js

Page $14 / 17$ 
68. Shah Alam, S., Ali, M. Y., \& Mohd. Jani, M. F. (2011). An empirical study of factors affecting electronic commerce adoption among SMEs in Malaysia. Journal of business economics and management, 12(2), 375-399

69. Shahzad, A., Hassan, R., Abdullah, N. I., Hussain, A., \& Fareed, M. (2020). Covid-19 impact on e-commerce usage: An empirical evidence from Malaysian healthcare industry. Humanities \& Social Sciences Reviews, 8(3), 599-609

70. Shorten, A., \& Smith, J. (2017). Mixed methods research: Expanding the evidence base. Evidence-Based Nursing, 20(3), 74-75

71. Singh, J., Flaherty, K., Sohi, R. S., Deeter-Schmelz, D., Habel, J., Le Meunier-FitzHugh, K., et al. (2019). Sales profession and professionals in the age of digitization and artificial intelligence technologies: concepts, priorities, and questions. Journal of Personal Selling \& Sales Management, 39(1), 2-22

72. Smeets, K., \& Zeisberger, S. (2020). How FinTech can help Latin America to deal with economic challenges and the Covid-19 crisis. Available at SSRN 3673240

73. Taleby Ahvanooey, M., Li, Q., Zhu, X., Alazab, M., \& Zhang, J. (2020). ANiTW: A Novel Intelligent Text Watermarking technique for forensic identification of spurious information on social media.Computers and Security, 90

74. Thames, L., \& Schaefer, D. (2016). Software-defined Cloud Manufacturing for Industry 4.0. Paper presented at the Procedia CIRP

75. Thorgren, S., \& Williams, T. A. (2020). Staying alive during an unfolding crisis: How SMEs ward off impending disaster. Journal of Business Venturing Insights, 14

76. Untaru, E. N., \& Han, H. (2021). Protective measures against Covid-19 and the business strategies of the retail enterprises: Differences in gender, age, education, and income among shoppers. Journal of Retailing and Consumer Services, 60(January), 102446-102446

77. Verma, S., \& Gustafsson, A. (2020). Investigating the emerging Covid-19 research trends in the field of business and management: A bibliometric analysis approach. Journal of Business Research, 118(June), 253-261

78. Winarsih, Indriastuti, M., \& Fuad, K. (2021). Impact of Covid-19 on digital transformation and sustainability in small and medium enterprises (smes): a conceptual framework. Vol. 1194 AISC. Advances in Intelligent Systems and Computing (pp. 471-476)

79. Zafar, A., \& Mustafa, S. (2017). SMEs and its role in economic and socio-economic development of Pakistan. International Journal of Academic Research in Accounting, Finance and Management Sciences, 6(4)

\section{Figures}

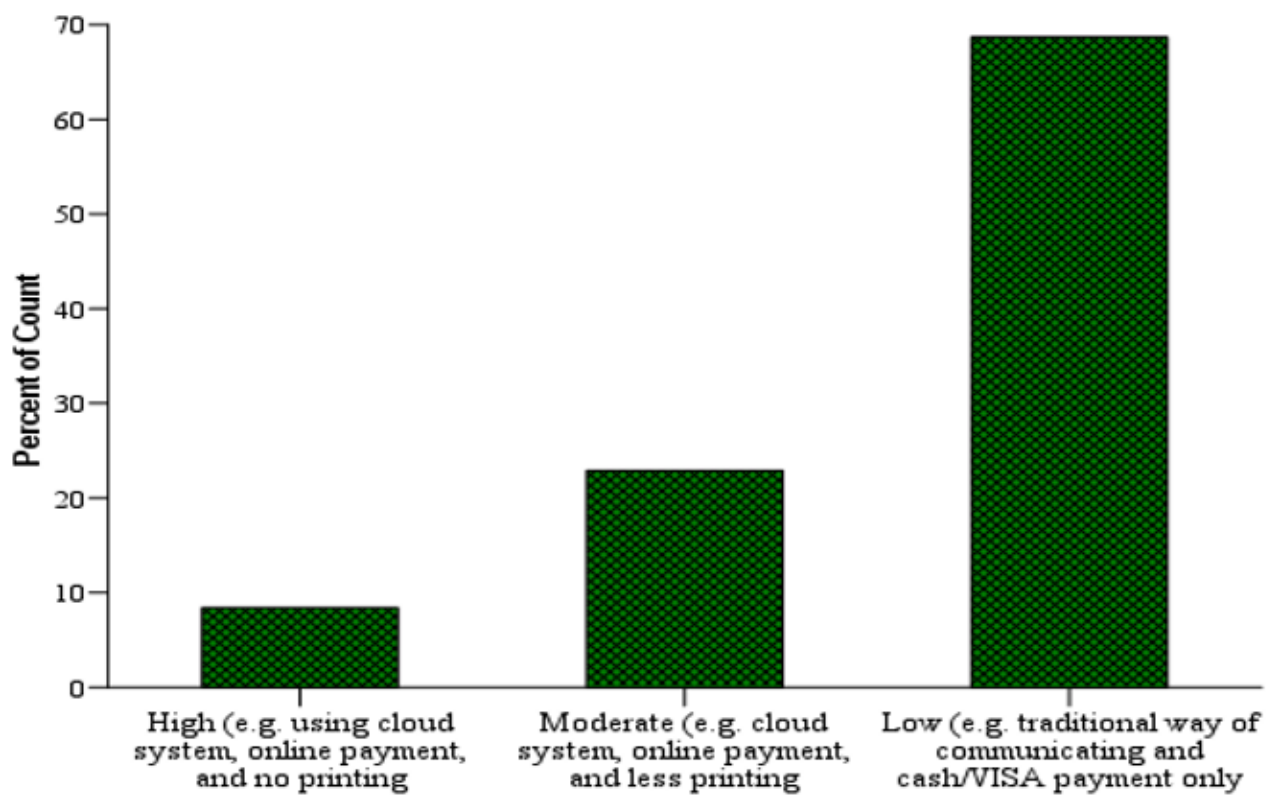

Figure 1

Level of digitization in SMEs in Oman 


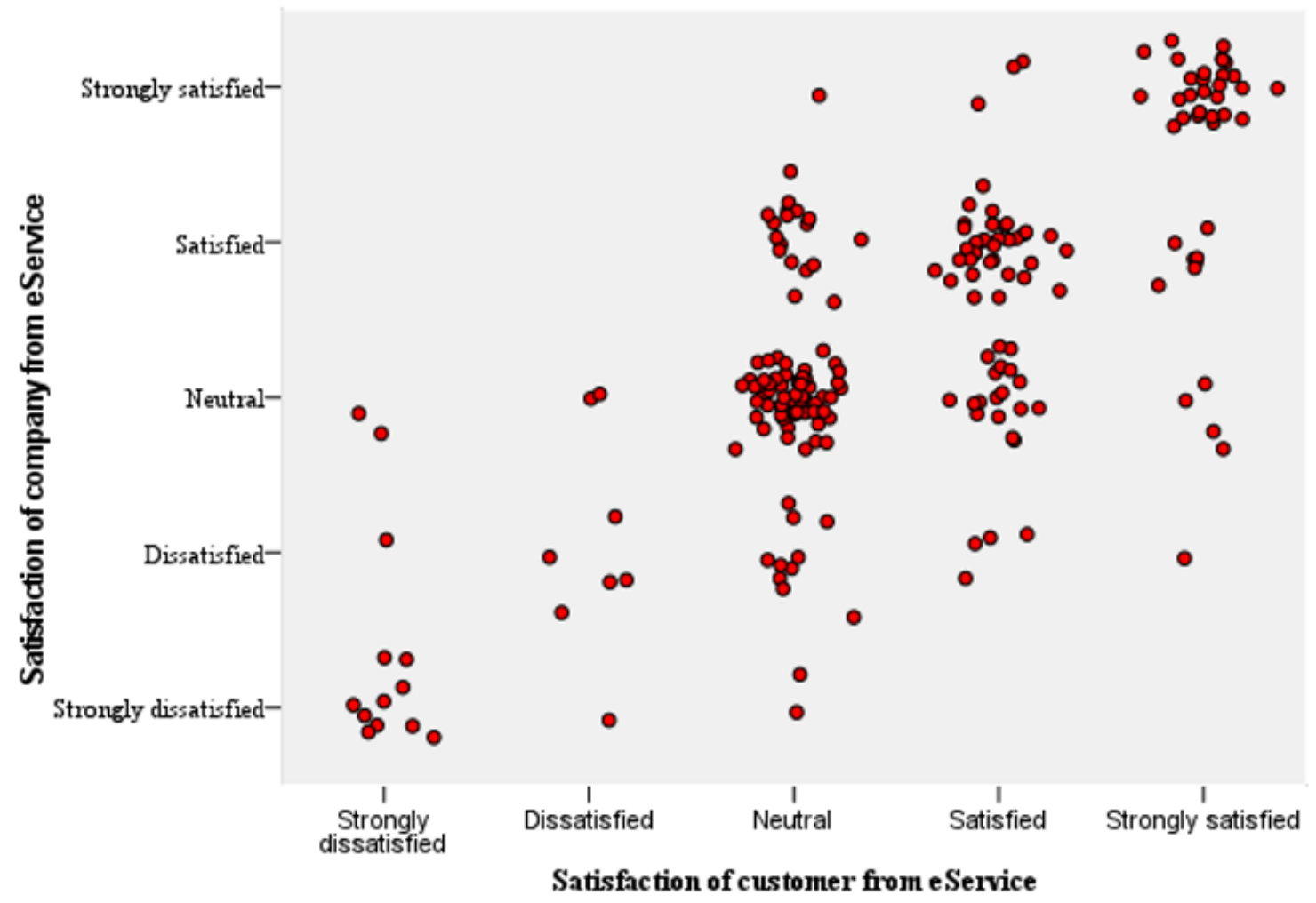

Figure 2

Satisfaction of customers and companies with eService during Covid-19



Figure 3

Participants' willingness to use Industry 4.0 technology in terms of types and percentage 


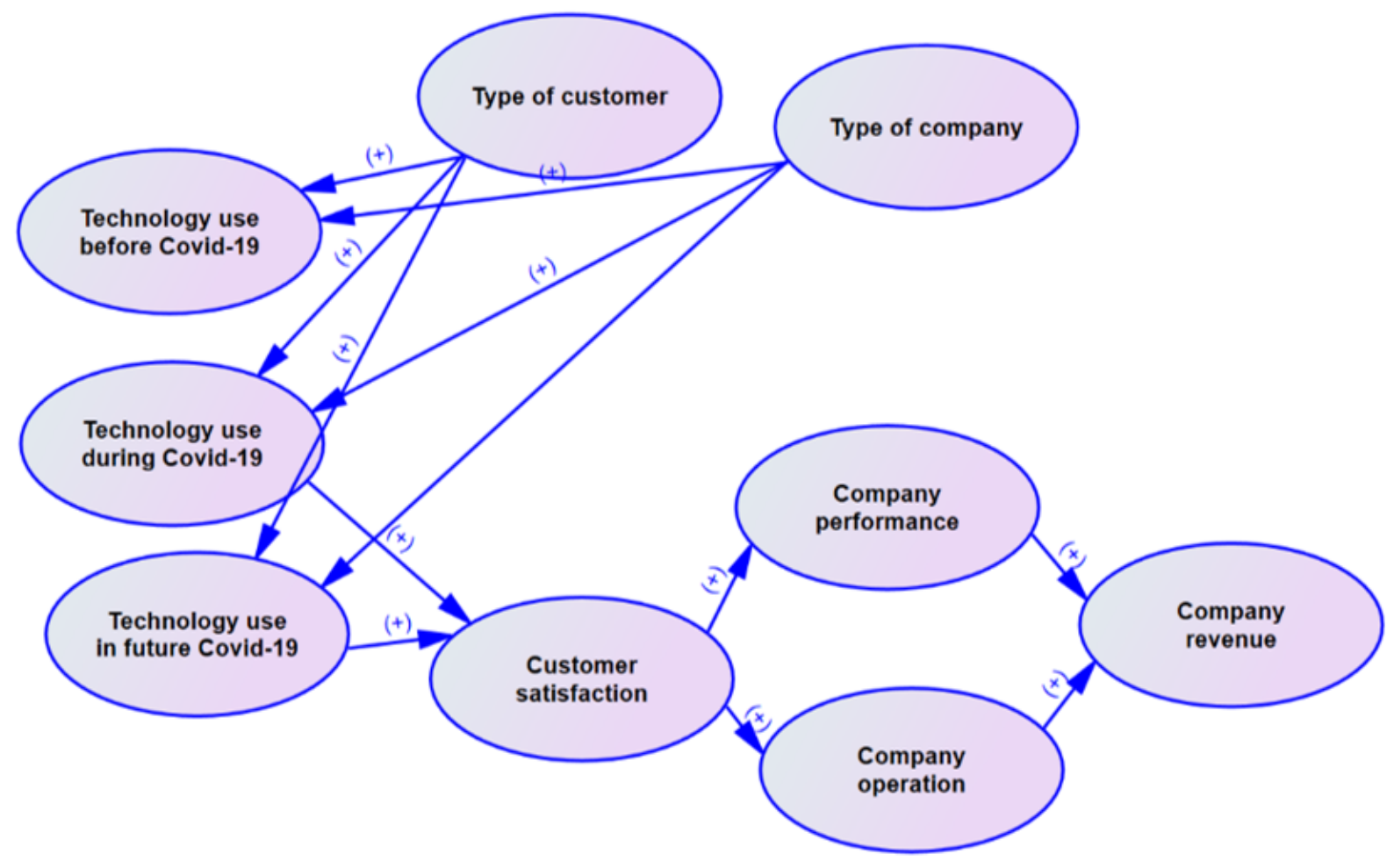

Figure 4

Relationship between selected variables 